\title{
An Investigation into the Determinant of Jordanian Customer's Loyalty towards Travel Agencies
}

\author{
Ahmad Bahjat Shammout ${ }^{1} \&$ Raed S. Algharabat ${ }^{2}$ \\ ${ }^{1}$ Al-Balqa Applied University, Amman, Jordan \\ ${ }^{2}$ Department of Marketing, Faculty of Business, The University Of Jordan, Jordan \\ Correspondence: Ahmad Bahjat Shammout, Department of Business Administration, Amman University \\ College, Al-Balqa Applied University, Amman 1705, Jordan. E-mail: ahmad.b.shammout@gmail.com
}

Received: July 28, $2013 \quad$ Accepted: August 19, $2013 \quad$ Online Published: November 7, 2013

doi:10.5539/ijms.v5n6p122 URL: http://dx.doi.org/10.5539/ijms.v5n6p122

\begin{abstract}
Relationship marketing aims to build and maintain relationships between customers and organizations. While keeping customers loyal is a key objective for service firms such as travel agencies, critical antecedents of customer loyalty still need to be understood. This study aims to empirically investigate the associations among relational bonds (including, financial, social and structural), customer emotions, trust, commitment and customer loyalty. The research is based on data collected from 319 Jordanian customers of Jordan travel agencies. The results of an integrated SEM suggest that financial, social and structural relational bonds contribute to customers' emotions and that these emotions are important determinants of customer trust, which impact customer commitment. In return customer commitment predicts customer loyalty. Implications for research and practice are derived.
\end{abstract}

Keywords: relationship marketing, relational bonds, customer emotions, trust, commitment and behavioural loyalty

\section{Introduction}

Relationship marketing is of considerable interest both academically and practically (Berry, 1995; Payne, 2000; Egan, 2004). The term 'relationship marketing' was introduced in the context of professional services by Berry (1983). Subsequently, the 'relationship marketing' concept became globally accepted as a new paradigm in the 1990s (i.e., Crosby, Evans \& Cowles, 1990; Grönroos, 1994; Gummeson, 1995; Morgan \& Hunt, 1994; Sheth \& Parvatiyar, 1995). This new paradigm includes a range of marketing activities (Palmer, 2000), shifting emphasise from short-term transactions to long-term relations (Dwyer, Schur \& Oh, 1987; Lin, Weng \& Hesieh, 2003), and aims to retain profitable customers and make them loyal by building a strong relationship. This is imperative because it has been suggested by many authors that loyalty is a relational phenomenon (e.g., Jacopy \& Kyner, 1973; Sheth \& Parvatiyar, 1995). Thus, it is considered as the most important aspect of buyer-seller relationships (Palmer, 1994), central to the paradigm of relationship marketing (Hart, Smith, Spark \& Nikolaos, 1999). The significance of this concept generates from the idea that maintaining a loyal customer is five to ten times more profitable than acquiring a new one, because: (i) the cost of serving loyal customers is less, (ii) fewer loyal customers are price sensitive and (iii) loyal customers spend more with the company (Berry \& Parasuraman, 1991; Bowen \& Shoemaker, 1998; Dowling \& Uncle, 1997; Noon, Kimes \& Renaghan, 2003; Tepeci, 1999).

For these reasons, travel agencies like other service providers are keen to maximize favorable customer intentions, particularly customer loyalty (Lobo, Maritz, \& Mehta, 2007). To achieve this goal, it has been widely accepted that relational bonds are cornerstones for keeping customers loyal to the firm (Berry, 1995; Wang, Liang, \& Wu, 2006). Furthermore, customer relationships cannot exist without emotional content (Barnes, 1997) and successful relationships require trust and commitment (Morgan \& Hunt, 1994). However, how customer loyalty is achieved based on the relationships between these important antecedents remains neglected in the previous research. Therefore, the purpose of this research is to empirically investigate the association between relational bonds (including financial, social and structural), customer emotions, trust and commitment and treat them as critical determinants of customer loyalty. 


\section{Literature Review and Conceptual Framework}

\subsection{Relational Bonds}

Relational bonds have been defined as "psychological, emotional, economic, or physical attachment in a relationship that are fostered by association and interaction and serve to bind parties together under relational exchange" (Smith, 1998, p.78). Early work by Berry and Parsuraman (1991) and Berry (1995), identified relationship marketing as being practiced on multiple levels using three broad categories of bonds to secure customer loyalty, moving from financial to social and then on to structural bonds. The first level involves financial bonds or incentives (Lin et al., 2003). The second level of relationship marketing focuses on the social bonds that develop personalisation and emotional connections in the relationship (Han, 1991). The third level of relationship marketing involves structural bond or solutions to customer problems (Smith, 1998). Following Berry and Parsuraman's (1991) classification, the three types of relational bonds (including financial, social and structural) have been widely used in previous research, particularly within the tourism and hospitality contexts (e.g. Campbell, John \& Phillip, 2006; Jain and Jain, 2005; Moliner, Sánchez, Rodríguez, \& Callarisa, 2006).

The research model and the hypothesized relationships among its variables which are all developed based on relevant literature. As shown in Figure 1, the model consists of seven interrelated latent variables: financial bonds, social bonds, structural bonds, emotion, trust, commitment and behavioural loyalty.

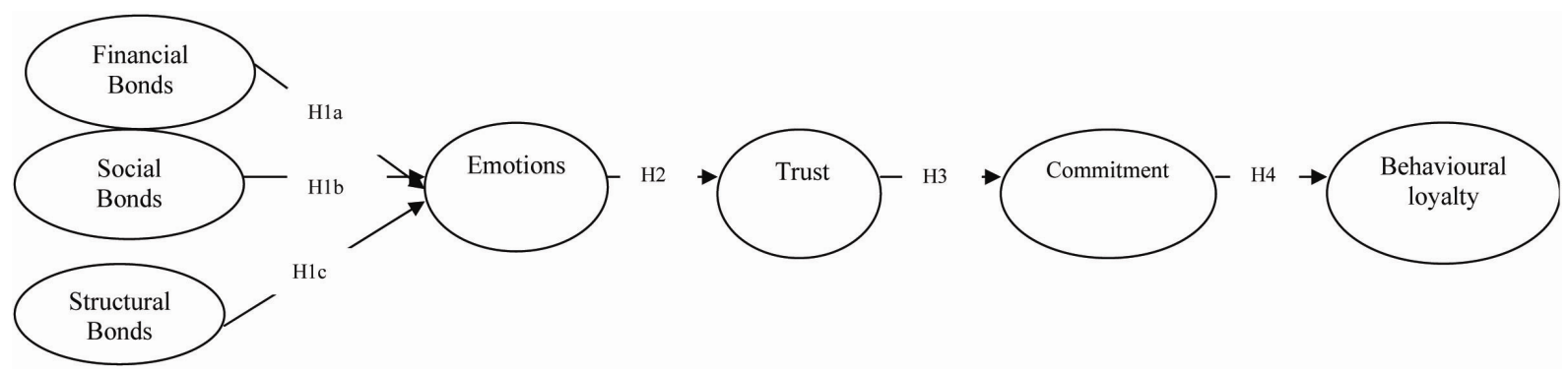

Figure 1. Conceptual framework

\subsubsection{Financial Bonds and Emotions}

Financial bonds are usually referred to as frequency marketing or retention marketing, where the service provider uses economic benefits such as price, discounts and other financial incentives to secure customer loyalty (Berry \& Parsuraman, 1991; Berry, 1995; Hsieh, Chiu, \& Chiang, 2005; Lin et al., 2003). Smith (1998, p.79) proposes that within business-to-business financial incentives are functional bonds or "the multiplicity of economic, performance, or instrumental ties or linkages that serve to promote continuity in a relationship". Functional bonds are created through economic, strategic, technological (knowledge or information), and instrumental (product or service related) benefits that are derived by the parties. Moreover, non-monetary time saving processes have also been proposed as a finical bond (Lin et al., 2003).

Pervious empirical research has found that financial bonds need to be modelled in addition to other relational bonds in consumer market, such social and structure, as saving money is only one motivation for engaging in a relationship with the service providers (Berry, 1995; Hsieh et al., 2005; Liang \& Wang, 2008; Lin et al., 2003; Peterson, 1995; Wang, Liang \& Wu, 2006). Within a tourism context, financial bonds would include loyalty programs where members can obtain free or discounted travel services and reward cards (Palmer, 2000). For example, Delta Airlines offers a cumulative points reward such as a "corporate privilege" program that links the Fort and Le Meridien Hotels and Resorts through a SkyMiles partnership. Delta Airlines describes the offer of this program as "what a good relationship is made of" (Stern, 1997, p.9). This kind of offer, according to Stern, makes Delta capable of establishing a relationship that can transform harried, stressed, groups of passengers into relaxed, comfortable, loved individuals. Therefore, the following hypothesize is posited:

H1a: Financial bonds will positively affect customer emotions.

\subsubsection{Social Bonds and Emotions}

In an early work, Han (1991, p.61) describes social bonds as "the degree to which certain ties link and hold a buyer and seller together closely in a personal (emotional sense). Such ties consist of many aspects including familiarity, friendship, social support, staying in touch, self-disclosure, or any interpersonal interaction". These 
aspects measure the strength of personal relationship between two parties, buyer and seller. Zithaml and Bitner (1996) addressed that social bond can be derived from customer-provider interactions and friendships in addition to customer-customer interactions. In customer-provider interaction, marketers always stress on staying in touch with their clients, learning about their needs, expressing their friendship (Berry, 1995; Williams, Han \& Qualls, 1998) and sharing their values (Voss \& Voss, 1997). Friendship and closeness in long-term relationships between service providers such as travel agencies and their customers are deemed to be important. That is, social bonds link and hold buyer and seller together in personal relationships that result in a positive emotional attachment (Han, 1991). Conversely, termination of personal relationships is a significant source of emotional stress (Dwyer et al., 1987). With that in mind, the following hypothesis is proposed:

H1b: Social bonds will positively affect customer emotions.

\subsubsection{Structural Bonds and Emotions}

Structural bonds are considered to be the highest level of bonding within relationship marketing because the fact that companies can strength their relationships with customers by adding structural bridges in addition to the financial and social bonds (Berry, 1995; Campbell et al. 2006). Structural bonds exist when a business enhances customer relationships by offering solutions to customer problems in the form of service-delivery systems, rather than remaining dependent upon the relationship building skills of individual service providers (Lin et al., 2003; Sheth \& Parvatiyar, 2000). This type of bonds is necessary for tourism services, because they provide embedded value-adding services for customers that are not readily copied by a competitor (Berry \& Parasuraman, 1991). For instance, hoteliers use of telecom and IT facilities for enhancing guest services, latest technology for better quality of services, expertise of service professionals in their areas of operation, providing relevant information to the guests, relying on the organization for taking decisions for their benefit and welfare, and careful evaluation of the guest's needs (Jain \& Jain, 2006). That is, competitors find difficulty to emulate such services due to the high costs in transformation. Since structural bonds build customer feelings of 'empowerment' and offer some level of psychological control to customers in the buyer-seller relationship (Peltier \&Westfall, 2000), we hypothesize that:

H1c: Structural bonds will positively affect customer emotions.

\subsection{Emotions and Trust}

Emotions have been described as "a mental state of readiness that arises from cognitive appraisals of an events or thoughts; has a phenomenological tone; is accompanied by physiological processes; is often expressed physically; and may result in specific actions to affirm or cope with the emotion, depending on its nature and the person having it" (Bagozzi, Gopinath \& Nyer, 1999, p. 184). It is suggested that emotions are specific to a product (Holbrook, Chestnut \& Oliva, 1984), service (Price, Arnould \& Tierney, 1995), consumption experience (Richins, 1997), advertisement (Batra \& Holbrook, 1990), or the relationship between buyer and seller (Barnes, 1997, Ruth, Brunel \& Otens, 2004). Researchers in relationship marketing have used different scales to investigate the role of emotions. For example, in an attempt to assess the closeness of relationships, Barnes (1997) acknowledged that these cannot exist without emotional content, and adopted ten different emotions (five positive and five negative) to focus on the concept of emotional tone (which is the difference between total positive and total negative emotions; i.e. it is positive if positive emotions are stronger than negative emotions). Liljandar and Strandvik (1997) included seven emotions (three positive and four negative) and argue that emotions could be presented in all interactions between the customer and service provider. As a result, past experiences may affect perceived emotions either positively or negatively. Similarly, Ruth et al. (2004) maintain that once positive or negative emotions are experienced, the overall preconceptions of the recipients to their relationship are also positive or negative. In their affect on other relational outcomes, Guerrero, Anderson and Trost (1998) argue that recipients experience multiple emotions that may systematically correspond to relationship outcomes. Further, Yizhen, Zhiwei and Ying (2012) assert a positive relationship between affect and trust. Liang and Wang (2008) posit a positive relationship between emotion and trust. However, the effect of experienced emotions in customer relationships considered as a factor of an affective and cognitive structure influencing outcome which has not been discussed and empirically studied in marketing literature (Sanchez-Franco \& Rondan-Catalun, 2010). In response, we propose that if travel agencies aim to keep their customers loyal, trust should be modeled as a consequence of customer emotions. This particularly important because when a person has been asked to give trust in an unfamiliar situation, then incidental gratitude and happiness increases trust, whereas incidental anger decreases trust (Dunn \& Schweitzer, 2005). Consequently, the following hypothesis is advanced:

H2: Customer emotions will positively affect customer trust. 


\subsection{Trust and Commitment}

Authors of relationship marketing in general agree that trust is one of the most important dimensions framing the relationship between buyers and sellers (e.g. De Wulf et al., 2001; Lin et al, 2003; Morgan \& Hunt, 1994; Wang et al., 2006). The development of trust is thought to be an important result of investing in dyadic buyer-seller relationships (Gundlach, Achrol \& Mentzer, 1995). Chow and Holden (1997) argue that the more trusting a relationship, the higher the value a customer places on the relationship. In return, the customer is more likely to maintain a trusting relationship than risk uncertainty in the building of new exchange processes. That is, uncertainty implies a potential for service failures and thus negative outcomes (Crosby et al., 1990).

In conceptualizing trust, authors usually distinguish between two types: trust in an entity's credibility and trust in an entity's benevolence (Kumar, Shcheer, \& Steenkamp, 1995). The first one focuses on the extent to which customer believe that service provider's word can be riled on, they are sincere and they will perform their role effectively and reliably (Ganesan, 1994; Kumar et al., 1995), while the second one focuses on a customer's perception of the extent to which the service provider is concerned about the welfare of the customer (Kumar et al., 1995). These two dimensions, therefore, has been used to capture trust in this study.

Previous research (e.g., Beatty, Coleman, \& Reynolds, 1996; Gundlach \& Murphy, 1993; Ramsey \& Sohi, 1997; Schurr \& Ozanne, 1985) posits that trust positively affects commitment. Furthermore, De Wulf \& Odekerken-Schroder (2003) assert the positive relationship between trust and relationship commitment. They state that this relationship often; (i) reduces perceived risk, (ii) increases the confidence of the buyer, and (iii) reduces the transaction costs in an exchange relationship. Thus it is expected that such benefits often build attachment and create a desire to continue the relationship (Andaleeb, 1996; Ganesan, 1994). However, the current study is one of few studies investigating the relationship between trust and commitment in travel agency services industry context. Therefore, the following hypothesis is proposed:

H3: Customer trust will positively affect customer commitment.

\subsection{Commitment and Behavioural Loyalty}

Since the main objective of relationship marketing is to establish and maintain long-term relationships that translate into customer loyalty (Bowen \& Shoemaker; 1998; Kurtz \& Clow, 1998; Too, Souchon \& Thirkell, 2001), customer loyalty has been treated as the final dependent variable in this study. At a general level, loyalty can be described as "something that consumers may exhibit to brands, services, stores, product categories (e.g., cigarettes), and activities (e.g., swimming)" (Uncles, Dowling, \& Hammond, 2003, p.295). Relationship marketing literature (e.g., De Wulf et al., 2001; Liang \& Wang, 2008) has viewed customer loyalty as behavioural. This is particularly evident when it is linked with commitment. From behavioural perspective, loyalty generally has been defined in terms of purchases measures over a defined period of time. For instance, De Wulf et al. (2001) defined behavioural loyalty as a composite measure based on consumer's purchasing frequency and amount spent at a retailer compared with amount spent at other retailer from which the consumer buy. These measures include purchasing frequency (i.e., Liljander and Strandvik, 1993), proportion of purchases (i.e., Backman\& Crompton, 1991), purchase sequence (i.e., Kahn Kalwani \& Morrison, 1986), and probability of purchase (Massey, Montgomery, \& Morrison, 1970). Accordingly, this study views customer loyalty as behavioral

Berry and Parasuraman (1991, p.139) maintained that "relationships are built on the foundation of mutual commitment," and according to Morgan and Hunt (1994) commitment is regarded as an essential component for successful long-term relationships. It has also been considered to be an important outcome of good relational interaction (Dwyer et al., 1987). Commitment has been defined in different ways. For instance, Moorman, Zaltman \& Deshpanede (1992, p.312) viewed commitment as "enduring desiger to maintain a valuded relationship". Morgan and Hunt viewed it as "an exchange partner believing that an ongoing relationship with another is so important as to warrant maximum efforts at maintaining it" (1994, p.23).

In reviewing the literature, it has been suggested that commitment could be either affective, continuance, or normative. However, relationship marketing authors in general opertionalise commitment as affective commitment (Fullerton, 2005). This type of commitment has generally been treated as an attitudinal construct (Gundlach et al., 1995; Fullerton, 2005). In addressing the significance of this component, Roberts et al. (2003) acknowledged that of the various kinds of commitment, only affective commitment influences the degree to which a consumer wants to maintain a relationship with the firm. Therefore, we view commitment in this study as affective. 
Commitment has been found to have a positive impact on customer loyalty. Reichheld \& Sasser (1990) argue that committed customers are less likely to switch to a competitor simply due to a minor price increase, and thus tend to spend more than comparable non-committed customers. Gruen (1995) sees commitment as the motivator to act, rather than the act itself, and Too et al. (2001) found that customer loyalty was related positively to customer commitment to the relationship with their store. They hypothesized that commitment to the relationship between the company and the customer affects the level of customer loyalty. Furthermore, researchers including Garbrino \& Johnson (1999), Pritchard, Arnould \& Tierney (1999), and Fullerton (2005) found that commitment positively affects customer retention. Therefore, the following hypothesis is formulated:

H4: Customer commitment will positively affect behavioural loyalty.

\section{Methodology}

\subsection{Measures}

A self-administered questionnaire was used to collect the data to empirically examine the model. The questionnaire was developed using a 7-point Likert type scale ranging from $(1=$ strongly disagree $)$ to $(7=$ strongly agree), with the exception of the emotions construct which was represented on scales ranging from $(1=$ never) to $(7=$ very often). Because participants are non-English speakers, translation and back-translation procedure of the instrument was used as recommended by methodological authors (Brislin, 1973; Malhorta, 1996). In total, 39-items were adapted from previously tested and commonly used scales. The 19-items developed by Lin et al. (2003) were adapted to measure relational bonds, including financial, social and structural. Eight items developed by Barnes (1997), Rust \& Oliver (2000), Barky \& Nash (2002, and Ruth et al. (2004) were used to measure emotions. Nine items developed by Robert et al. (2003) were utilized to measure trust and commitment (i.e. 6- items were used to measure trust and 3- items were used to measure commitment). Behavioral loyalty was measured by adapting three items developed by Too et al. (2001). The instrument was pre-tested to ensure that the questions were clearly understood and there was no ambiguity among them.

\subsection{Sample}

The sample of this study was randomly selected and consists of loyal customers who were Jordanians and bought their packages from travel agencies in Jordan. Prior permission and co-operation was sought from five well common selected agencies in Jordan. To identify loyal customers, we used the definition that 'loyal customer' were individuals who used the services of a travel agent in the past 12 months (Lobo et al., 2007). The questionnaire was handed over face-to-face to 1200 travelling agency customers in Jordan. Among 367 received questionnaires, 319 were usable and used for further analysis, yielding a final response rate of 26 percent. The final sample consisted of 107 females ( 33.6 percent) and 212 males ( 66.4 percent). The majority ( 29.6 percent) of the subjects were in the age group of 45-54. Results also shows that most of them were tertiary educated, as 51.9 percent had completed an undergraduate degree.

\section{Results}

To test the proposed theoretical model, we used the two-stages approach of structural equation modelling (SEM) recommended by Anderson \& Gerbing (1998). The first stage (i.e. the measurement model) deals with the reliability and validity of the constructs, while the second stage (i.e. the structural model) deals with testing the hypothesized relationships.

\subsection{Exploratory Factor Analysis}

The analysis started by examining the structure and dimensionality of the study constructs using exploratory factor analysis (EFA) and reliability analysis. After examining the pattern matrix of the EFA, all items had loadings greater than 0.4 and communalities greater than 0.5 . Therefore, we ended up with 4 questions measuring financial bonds (FB), 4 questions measuring social bonds (SB), 4 questions measuring structural bonds (STB), 4 questions measuring emotions (EMOT), 3 questions measuring trust (TRU), 3 questions measuring commitment (COMM) and 3 questions measuring behavioural loyalty (BELO).

\subsection{Measurement Model}

We evaluated the measurement and structural equation models (SEM) using AMOS. The measurement model includes 25 indicators, and we provide its results in Table 1 including the standardised factor loading, standard error (SE), t-values, reliability, and average variance extracted (AVE). The standardised factor loadings $(\lambda)$ are all greater than .6. The composite reliabilities are all within the 'acceptable' range of greater than .70 (Hair et al., 1998). Moreover, AVE by each construct exceeds the minimum value (.5 or above) recommended by Hair et al. (1998), indicating convergent validity. 
Table 1. Results of the CFA within the three latent factors

\begin{tabular}{|c|c|c|c|c|c|c|c|c|c|}
\hline Indicator & Direction & Construct & $\begin{array}{l}\text { Standardised } \\
\text { Estimate }\end{array}$ & Estimate & SE & t-value & $\mathrm{P}$ & Reliability & AVE \\
\hline FB1 & $\leftarrow$ & FB & .75 & 1.00 & & & & .82 & .54 \\
\hline FB2 & $\leftarrow$ & FB & .77 & .824 & .107 & 7.684 & $* * *$ & & \\
\hline FB3 & $\leftarrow$ & FB & .69 & 699 & .122 & 8.170 & $* * *$ & & \\
\hline FB4 & $\leftarrow$ & FB & .73 & .820 & .114 & 7.184 & $* * *$ & & \\
\hline SB1 & $\leftarrow$ & SB & .63 & 1.00 & & & & .85 & .58 \\
\hline SB2 & $\leftarrow$ & SB & .85 & .961 & .050 & 6.122 & $* * *$ & & \\
\hline SB3 & $\leftarrow$ & SB & .69 & .884 & .048 & 7.486 & $* * *$ & & \\
\hline SB4 & $\leftarrow$ & SB & .86 & 1.00 & .045 & 8.456 & $* * *$ & & \\
\hline STB1 & $\leftarrow$ & STB & .85 & 1.00 & & & & .88 & .59 \\
\hline STB2 & $\leftarrow$ & STB & .82 & .352 & .120 & 5.160 & $* * *$ & & \\
\hline STB3 & $\leftarrow$ & STB & .70 & .451 & .064 & 6.342 & $* * *$ & & \\
\hline STB4 & $\leftarrow$ & STB & .82 & .362 & .056 & 7.251 & $* * *$ & & \\
\hline EMOT1 & $\leftarrow$ & EMOT & .73 & 1.00 & & & & .85 & .69 \\
\hline EMOT2 & $\leftarrow$ & EMOT & .80 & .621 & .12 & 8.284 & $* * *$ & & \\
\hline EMOT3 & $\leftarrow$ & EMOT & .75 & .450 & .35 & 9.214 & $* * *$ & & \\
\hline EMOT4 & $\leftarrow$ & EMOT & .80 & .235 & .40 & 6.214 & $* * *$ & & \\
\hline TRU1 & $\leftarrow$ & TRU & .75 & 1.00 & & & & .85 & .65 \\
\hline TRU2 & $\leftarrow$ & TRU & .86 & .126 & .025 & 6.371 & $* * *$ & & \\
\hline TRU3 & $\leftarrow$ & TRU & .81 & .143 & .035 & 7.361 & $* * *$ & & \\
\hline COMM1 & $\leftarrow$ & COMM & .80 & 1.00 & & & & & \\
\hline COMM2 & $\leftarrow$ & COMM & .75 & .325 & .026 & 6.344 & $* * *$ & & \\
\hline COMM3 & $\leftarrow$ & COMM & .69 & .542 & .036 & 8.36 & $* * *$ & .79 & .56 \\
\hline BELO1 & $\leftarrow$ & BELO & .90 & 1.00 & & & & .93 & .82 \\
\hline BELO2 & $\leftarrow$ & BELO & .92 & .364 & .015 & 5.3871 & $* * *$ & & \\
\hline BELO3 & $\leftarrow$ & BELO & .89 & .325 & .026 & 6.452 & $* * *$ & & \\
\hline
\end{tabular}

The square roots of the average variance extracted by each construct exceed the correlation between them (Table 2), demonstrating discriminant validity. Thus, our instrument had satisfactory construct validity (Anderson and Gerbing, 1988; Fornell and Larcker, 1981). The results of the measurement model demonstrated that the data reasonably fit the model; $\chi 2=301.055, \chi 2 / \mathrm{df}=1.185, \mathrm{GFI}=.933, \mathrm{AGFI}=.914, \mathrm{CFI}=.977, \mathrm{TLI}=.973$, RMSEA $=.024$.

Table 2. Internal consistency and discriminant validity of constructs

\begin{tabular}{llllllll}
\hline Construct & Correlation & & & & & & \\
& 1 & 2 & 3 & 4 & & & \\
\hline 1. FB & .73 & & & & & & \\
2. SB & .42 & .76 & & & & & \\
3. STB & .52 & .25 & .77 & & & \\
4. EMOT & .35 & .42 & .48 & .83 & .80 & & \\
5. TRU & .15 & .24 & .36 & .40 & .30 & .75 \\
6. COMM & .24 & .27 & .19 & .14 & .30 & .25 \\
7. BELO & .25 & .56 & .26 & .34 & .25 & .91 \\
\hline
\end{tabular}

The figures under the diagonal are the Pearson (R) correlations between the variables. Diagonal elements are square roots of average variance extracted.

\subsection{Structural Model}

The hypothesised model achieves a chi-square of 485.275 ( $\mathrm{df}=269$ ), $x^{2} / \mathrm{df}=1.804, \mathrm{p}<0.001$, with GFI of .914 , CFI of .910, and RMSEA of .054. These results indicate that the model fit the data adequately (Byrne, 2010; Hair et al., 1998). The results also confirms that social bonds, structural bonds and financial bonds have 
significant positive effects on emotions $\left(\mathrm{H}_{1 \mathrm{a}} \beta=.42, p<0.001, \mathrm{t}=6.308 ; \mathrm{H}_{1 \mathrm{~b}} \beta=.29, p<0.001, \mathrm{H}_{1 \mathrm{c}} \beta=.45\right.$, $p<0.001)$. Moreover, emotions exhibits a significant positive effect on trust $\left(\mathrm{H}_{2} \beta=.50, p<0.001\right)$. As we hypothesised, trust has significant positive effects on commitment $\left(\mathrm{H}_{3} \beta=.32, p<0.001\right)$ and commitment has positive impact on behavioural loyalty $\left(\mathrm{H}_{4} \beta=.65, p<0.001\right)$. Finally, coefficient of determination $\left(\mathrm{R}^{2}\right)$ for emotions $=.56$, trust $=.48$, commitment $=.30$, and behavioural loyalty $=.51$.

\section{Discussion, Conclusion and Implications}

This study empirically developed our understanding regarding the importance of relational bonds, customer emotions, trust and commitment as crucial determinants in keeping customers loyal. Our results suggest that travel agencies in Jordan should look at relational activities as the main antecedents to enhance customers' positive emotions. In accordance with previous literature suggestion, we find that the three types of relational bonds, including financial, social and structural have a significant impact on emotions. For instance, receiving rewards from interaction with another party can make customers of travel agencies feel happy (Kelly, 1984). Also, using social bonds between travel agencies and customers link and hold them in interpersonal manner that result in a positive attachment. Furthermore, a significant relationship between structural bonds and emotions is implied when innovative products or different ways of interaction are provided by travel agencies to their customers.

As we proposed in our model, we find that emotions impact customers' level of trust. This suggests that as long as customers were happy with the relationships they have with their travel agencies, their trust will increase and vice versa if they were angry (Dunn \& Schweitzer, 2005). Our results also clearly reveal a significant relationship between trust and commitment, indicating that the more trust customers have in a travel agency the higher relationship commitment will be. In other words, once consumers feel trust with a travel agency's relationship efforts, customers' commitment to that travel agency become stronger. We find that the relation between commitment and behavioural loyalty is positive. Consumers' commitment to a travel agency has positive effects on consumers' behavioural loyalty. Therefore, commitment is only an antecedent of behavioural loyalty (Liand \& Wang, 2008).

Service managers should take into account that keeping customers loyal is not an easy job to do, because the development and sustainability of customer loyalty is difficult and still surrounded with some ambiguity in terms of its determinants (Liang \& Wang, 2008). However, there is a necessity to achieve customer loyalty, because previous research on tourism maintains that a small increase in loyal customers will result in a substantial increase in profitability (e.g. Bowen \& Shoemaker, 1998; Tepeci, 1999). With that in mind, our findings have implications for mangers of travel agencies. There is a need to implement relational strategies such as, financial, social and structural, as they are important and it seems that customers take them as granted. These relational strategies should be designed in a way that influnce relational outcomes. For instance, travel agencies' customers are more able to show positive emotions and high level of trust and commitment if the implementation of relational strategies exceeds their expectations or at least meets them because they are associated with each other. This suggests that these relational outcomes are crucial in developing and maintain customer loyalty and mangers should pay attention to them.

\section{Limitations and Directions for Further Research}

We admit having the following limitations. First, caution might be taken about generalising the results of this study, as it reflects Jordanian customers'. In investigating relationships, Sheth \& Partivayar (1995) point out that because of culture differences customers may see their relationships with their service providers differently. This therefore requires more cross-cultural research to see whether customers from other cultures have similar views, or there is something special to Jordanian customers. Second, this research investigates the hypothesized model in the context of travel agencies. Future research could see whether the results will be different according to different industries. Finally, additional research is required to expand our understanding of the constructs used in this research, by using different ways to investigate them. For instance, Barsky \& Nash (2002) provide us with certain words for positive emotions that loyal customer feel during their stay at five-star hotels. Therefore, there is a need to understand whether customers of travel agencies express their feeling by using certain positive or negative words.

\section{References}

Anderson, J. C., \& Gerbing, D. W. (1988). Structural Equation Modeling in Practice: A Review and Recommended Two-Step Approach. Psychological Bulletin, 103, 411-423. 
Backman, C. W., \& Crompton, J. L. (1991). The usefulness of selected variables for predicting activity loyalty. Leisure Sciences, 13, 205-220. http://dx.doi.org/10.1080/01490409109513138

Bagozzi, R. P., Gopinath, M., \& Nyer, P. U. (1999). The role of emotions in marketing. Journal of the Academy of Marketing Science, 27(2), 184-206. http://dx.doi.org/10.1177/0092070399272005

Barnes, J. G. (1997). Closeness, strength, and satisfaction: Examining the nature of relationships between providers of financial services and their retail customers. Psychology \& Marketing, 14(8), 765. http://dx.doi.org/10.1002/(SICI)1520-6793(199712)

Barsky, J., \& Nash, L. (2002). Evoking emotion: Affective keys to hotel loyalty. Cornell Hotel \& Restaurant Administration Quarterly, 43(1), 39-46. http://dx.doi.org/10.1016/S0010-804(02)80007-6

Batra, R., \& Holbrook, M. B. (1990). Developing a typology of affective responses to advertising: A test of validity and reliability. Psychology \& Marketing, 7(Spring), 11-25. http://dx.doi.org/10.1002/mar.4220070103

Beatty, S. E., Coleman, J. E., Reynolds, K. E., \& Lee, J. (1996). Customer-sales associate retail relationships. Journal of Retailing, 72(3), 223-247. http://dx.doi.org/10.1016/S0022-4359(96)90028-7

Berry, L. L. (1983). Relationship marketing. In Berry, L. L., G. L. Shostack \& G. D. Upah (Eds.), An Emerging Perspective on Services Marketing (pp. 25-28). Chicago: American Marketing Association.

Berry, L. L. (1995). Relationship marketing of services-growing interest, emerging perspectives. Journal of the Academy of Marketing Science, 23(4), 236-245. http://dx.doi.org/10.1177/009207039502300402

Berry, L. L., \& Parasuraman, A. (1991). Marketing Service-Competing Through Quality. New York: The Free Press. http://dx.doi.org/10.1016/S0010-8804(02)80007-6

Bowen, J., \& Shoemaker, S. (1998). Loyalty: a strategic commitment. Cornell Hotel and Restaurant Administration Quarterly, 12-25. http://dx.doi.org/10.1177/001088049803900104

Brislin, R., Lonner, W., \& Thorndike, R. (1973). Cross-Cultural Research Methods. New York: Wiley-Interscience.

Byrne, B. M. (2010). Structural Equation Modeling with AMOS: Basic Concepts, Applications, and Programming (2nd ed.). New York, NY: Taylor and Francis Group, LLC.

Campbell, T. T., John, D. N., \& Phillip, J. K. (2006). The importance of social bonding and loyalty: an empirical investigation within UK private health clubs. Journal of Hospitality \& Leisure Marketing, 14(1), 49-73. http://dx.doi.org/10.1300/J150v14n01_04

Chow, S., \& Holden, R. (1997). Towards an understanding of loyalty: The moderating role of trust. Journal of Managerial Issues, 9(3), 275-298.

Crosby, L. A., Evans, K. R., \& Cowles, D. (1990). Relationship quality in services selling: An interpersonal influence perspective. Journal of Marketing, 54, 68-81. http://dx.doi.org/10.2307/1251817

De Wulf, K., Odekerken-Schröder, G., \& Iacobucci, D. (2001). Investments in Consumer Relationships: A Cross-Country and Cross-Industry Explanation. Journal of Marketing, 65(October), 33-50. http://dx.doi.org/10.1509/jmkg.65.4.33.18386

Dowling, G. R., \& Uncles, M. (1997). Do customer loyalty programs really work? Sloan Management Review, $71-82$.

Dunn, J. R., \& Schweitzer, M. E. (2005). Feeling and believing: The influence of emotion on trust. Journal of Personality and Social Psychology, 88(5), 736-748. http://dx.doi.org/10.1037/0022-3514.88.5.736

Dwyer, F. R., Schur, P. H., \& Oh, S. (1987). Developing buyer-seller relationships. Journal of Marketing, 51, $11-27$.

Egan, J. (2004). Relationship Marketing: Exploring Relational Strategies in Marketing. Harlow: Prentice Hall.

Fornell, C., \& Larcker, D. F. (1981). Evaluating structural equation models with unobservable variables and measurement error. Journal of Marketing Research, 18(1), 39-50.

Fullerton, G. (2005). How commitment both enables and undermines marketing relationships. European Journal of Marketing, 39(11/12), 1372-1388. http://dx.doi.org/10.1108/03090560510623307

Ganesan, S. (1994). Determinants of long-term orientation in buyer-seller relationships. Journal of Marketing, 58(2), 1-19. http://dx.doi.org/10.2307/1252265 
Garbarino, E., \& Johnson, M. (1999). The different roles of satisfaction, trust, and commitment in customer relationships. Journal of Marketing, 63(2), 70-87. http://dx.doi.org/10.2307/1251946

Grönroos, C. (1994). From marketing mix to relationship marketing: towards a paradigm shift in marketing. Management Decision, 32(2), 4-20. http://dx.doi.org/10.1108/00251749410054774

Gruen, T. W. (1995). The outcome set of relationship marketing in consumer markets. International Business Review, 4(4), 447-469. http://dx.doi.org/10.1016/0969-5931(95)00026-7

Guerrero, L. K., Anderson, P. A., \& Trost, M. R. (1998). Communication and emotion: basic concept and approach. In P. A. Anderson \& L. K. Guerrero (Eds.), Handbook of Communication and emotion; research, theory, application and contexts (pp. 3-27). San Diego: Academic Press.

Gummesson, E. (1995). Relationship marketing. European Journal of Marketing, 29(5), 76-77.

Gundlach, G. T., \& Murphy, P. E. (1993). Ethical and legal foundations of relational marketing exchanges. Journal of Marketing, 57(4), 35-46.

Gundlach, G. T., Achrol, R. S., \& Mentzer, J. T. (1995). The structure of commitment in exchange. Journal of Marketing, 59(1), 78-92.

Hair, J. A. R., Tatham, R., \& Black, W. (1998). Multivariate Data Analysis. Upper Saddle River, NJ: Prentice-Hall.

Han, S. (1991). Antecedents of Buyer-Seller Long-Term Relationships: An Exploratory Model of Structural Bonding and Social Bonding, Unpublished Doctoral Dissertation. Department of Marketing. The Pennsylvania State University.

Hart, S., Smith, A, Spark, L., \& Nikolaos, T. (1999). Are loyalty schemes a manifestation of relationship marketing? Journal of Marketing Management, 15, 541-562. http://dx.doi.org/10.1362/026725799785045842

Holbrook, M. B., Chestnut, R. W., Oliva, T. A., \& Greenleaf, E. A. (1984). Play as a consumption experience: The role of emotions, performance, and personality in the enjoyment of games. Journal of Consumer Research, 11(2), 728-739. http://dx.doi.org/10.1086/209009

Hsieh, Y., Chiu, H., \& Chiang, M. (2005). Maintaining a committed online customer: a study cross search-experience-credence products. Journal of Retailing, 81(1), 75-82. http://dx.doi.org/10.1016/j.jretai.2005.01.006

Jacopy, J., \& Kyner, D. B. (1973). Brand loyalty versus repeat purchase behavior. Journal of Marketing Research, 10(February), 1-9.

Jain, R., \& Jain, S. (2005). Towards relational exchange services marketing: insight from hospitality industry. Journal of Services Research, 5(2), 139-150. http://dx.doi.org/10.1145/1655925.1656067

Kahn, B. E., Kalwani, M. U., \& Morrison, D. G. (1986). Measuring variety seeking and reinforcement behaviours using panel data. Journal of Marketing Research, 23(2), 89-100. http://dx.doi.org/10.2307/3151656

Kelley, H. H. (1984). Affect in relationships. In P. Shaver (Ed.), Review of Personality and Social Psychology: Emotions, Relationships and Health. Beverly Hills: Sage. http://dx.doi.org/10.1111/1467-9566

Kumar, N., Shcheer, L. K., \& Steenkamp, J. E. M. (1995). The effects of supplier fairness on vulnerable resellers. Journal of Marketing Research, 32(1), 54-65. http://dx.doi.org/10.2307/3152110

Kurtz, D. L., \& Clow, K. E. (1998). Services Marketing. New York: John Wiley \& Sons. http://dx.doi.org/10.1108/17410400410523756. 9.

Liang, C., \& Wang, W. (2008). Do loyal and more involved customers reciprocate retailer's relationship efforts? Journal of Services Research, 8(1), 64-90.

Liljander, V., \& Strandvik, T. (1993). Estimating zone of tolerance in perceived service quality and perceived service value. International Journal of Service Industry Management, 4(2), 6-28. http://dx.doi.org/10.1108/09564239310037909

Liljander, V., \& Strandvik, T. (1997). Emotions in service satisfaction. International Journal of Service Industry Management, 8, 148-169. http://dx.doi.org/ 10.1108/09564239710166272 
Lin, P., Weng, J. C. M., \& Hsieh, Y. (2003). Relational bonds and customer's trust and commitment- a study on the moderating effects of web site usage. The Services Industries Journal, 23(3), 103-127. http://dx.doi.org/10.1080/714005111

Lobo, A., Maritz, A., \& Mehta, S. (2007). Enhancing Singapore travel agencies' customer loyalty: an empirical investigation of customers' behavioural intentions and zones of tolerance. International Journal of Tourism Research, 9, 485-495. http://dx.doi.org/10.1002/jtr.619

Malhorta, N. K. (1996). Marketing Research: An Applied Orientation. New Jersey: Prentice-Hall.

Massey, W. F., Montgomery, D. B., \& Morrison, D. G. (1970). Stochastic Model of Buyer Behaviour. Cambridge: MIT Press.

Moliner, M. A., Sánchez, J., Rodríguez, R. M., \& Callarisa, L. (2007). Relationship quality with a travel agency: the influence of the post purchase perceived value of a tourism package. Tourism and Hospitality Research, 7(3/4), 194-211. http://dx.doi.org/10.1057/palgrave.thr.6050052

Moorman, C., Zaltman, G., \& Deshpanede, R. (1992). Relationship between providers and users of market research: The dynamics of trust within and between organizations. Journal of Marketing Research, 29(3), 314-329.

Morgan, M. R., \& Hunt, D. S. (1994). The commitment-trust theory of relationship marketing. Journal of Marketing, 58, 20-38. http://dx.doi.org/10.2307/1252308

Noon, B. M., Kimes, S. E., \& Renaghan, L. M. (2003). Integrating customer relationship management and revenue management: A hotel perspective. Journal of Revenue Management and Pricing Management, 2(1), 7-21. http://dx.doi.org/10.1057/palgrave.rpm.5170045

Palmer, A. (1994). Relationship marketing: Back to basic? Journal of Marketing Management, 10(7), 571-578. http://dx.doi.org/10.1080/0267257X.1994.9964305

Palmer. (2000). Buyer-seller relationship development. Principles of Marketing, 189-215.

Payne, A. (2000). Relationship marketing: the U.K perspective's. In Sheth, J. N., \& Parvatiyar, A. (Eds.), Handbook of Relationship Marketing. Thousand Oaks: Sage.

Peltier, J. W., \& Westfall, J. (2000). Dissecting the HMO-benefits managers relationship: what to measure and why. Marketing Health Services, 20(2), 4-13.

Peterson, R. A. (1995). Relationship marketing and the consumer. Journal of the Academy of Marketing Science, 23(4), 278-281. http://dx.doi.org/ 10.1177/009207039502300407

Price, L. L., Arnould, E. J., \& Tierney, P. (1995). Going to extremes: Managing service encounters and assessing provider performance. Journal of Marketing, 59(2), 83-97. http://dx.doi.org/ 10.2307/1252075

Pritchard, M. P., Havitz, M. E., \& Howard, D. R. (1999). Analysing the commitment-loyalty link in service contexts. Journal of The Academy of Marketing Science, 27(3), 333-348. http://dx.doi.org/10.1177/0092070399273004

Pullman, M. E., \& Gross, M. A. (2004). Ability of experience design elements to elicit emotions and loyalty behaviors. Decision Science, 35(3), 551-578. http://dx.doi.org/10.1111/j.0011-7315.2004.02611.x

Ramsey, R. P., \& Sohi, R. S. (1997). Listening to your customers: the impact of perceived salesperson listening behavior on relationship outcomes. Journal of the Academy of Marketing Science, 25(2), 127-137. http://dx.doi.org/10.1007/BF02894348

Reichheld, F. F., \& Sasser, W. E. (1990). Zero defections: Quality comes to services. Harvard Business Review, 68(5), 105-111.

Richins. (1997). Measuring emotions in the consumption experience. Journal of Consumer Research, 24(September), 127-146. http://dx.doi.org/10.1086/209499

Roberts, K., Varki, S., \& Brodie, R. (2003). Measuring the quality of relationships in consumer services: An empirical study. European Journal of Marketing, 37(1/2), 169-196. http://dx.doi.org/10.1108/03090560310454037

Rust, R. T., \& Oliver, R. L. (2000). Should we delight the customer? Journal of The Academy of Marketing Science, 28(1), 86-94. http://dx.doi.org/ 10.1177/0092070300281008 
Ruth, J. A., Brunel, F. F., \& Otens, C. C. (2004). An investigation of the power of emotions in relationship realignment: The gift recipient's perspective. Psychology \& Marketing, 21(1), 29-52. http://dx.doi.org/10.1086/20949910.1002/mar.10114

Sanchez-Franco, M., \& Rondan-Catalun, F. J. (2010). Connection between customer emotions and relationship quality in online music services. Behaviour \& Information Technology, 29(6), 633-651. http://dx.doi.org/10.1080/01449290903235343

Schurr, P. H., \& Ozanne, J. L. (1985). Influences on exchange processes: buyers' preconceptions of a seller's trustworthiness and bargaining toughness. Journal of Consumer Research, 11(4), 939-953. http://dx.doi.org/10.1086/209028

Sheth, J. N., \& Parvatiyar, A. (1995). Relationship marketing in consumer market: Antecedents and consequences. Journal of the Academy of Marketing Science, 23(4), 255-271. http://dx.doi.org/10.1177/009207039502300405

Smith, B. (1998). Buyer-seller relationship: Bonds, relationship management, and sex type. Canadian Journal of Administrative Sciences, 15(1), 76-92. http://dx.doi.org/10.1111/j.1936-4490.1998.tb00153.x

Stern, B. B. (1997). Advertising intimacy: Relationship marketing and the service consumer. Journal of Advertising, 26(4), 7-19. http://dx.doi.org/10.1080/00913367.1997.10673532

Tepeci, M. (1999). Increasing brand loyalty in the hospitality industry. International Journal of Contemporary Hospitality Management, 11(5), 223-229. http://dx.doi.org/10.1108/09596119910272757

Too, H. Y., Souchon, A. L., \& Thirkell, P. C. (2001). Relationship marketing and customer loyalty in a retail setting: A dyadic exploration. Journal of Marketing Management, 17, 287-319. http://dx.doi.org/30AQ100

Uncles, M. D., Dowling, G., \& Hammond, K. (2003). Customer loyalty and customer loyalty programs. Journal of Consumer Marketing, 20(4), 294-316. http://dx.doi.org/10.1108/07363760310483676

Voss, G. B., \& Voss, Z. G. (1997). Implementing a relationship marketing program: A case study and managerial implications. Journal of Service Marketing, 11(4), 278-298. http://dx.doi.org/10.1108/08876049710171731

Wang, W., Liang, C., \& Wu, Y. (2006). Relationship bonding tactics, relationship quality and customer behavioral loyalty-behavioral sequence in Taiwan's information service industry. Journal of Service Research, 6, 31-57. http://dx.doi.org/21558874

Williams, J. D., Han, S. L., \& Qualls, W. J. ( 1998). A conceptual model and study of cross-cultural business $\begin{array}{llll}\text { relationships. Journal of Business Research. } & \text { 42(2), }\end{array}$ http://dx.doi.org/10.1016/S0148-2963(97)00109-4

Zeithaml, V. A., Berry, L. L., \& Parasuraman, A. (1996). The behavioural consequences of service quality. Journal of Marketing, 60, 31-46. http://dx.doi.org/10.2307/1251929

\section{Copyrights}

Copyright for this article is retained by the author(s), with first publication rights granted to the journal.

This is an open-access article distributed under the terms and conditions of the Creative Commons Attribution license (http://creativecommons.org/licenses/by/3.0/). 